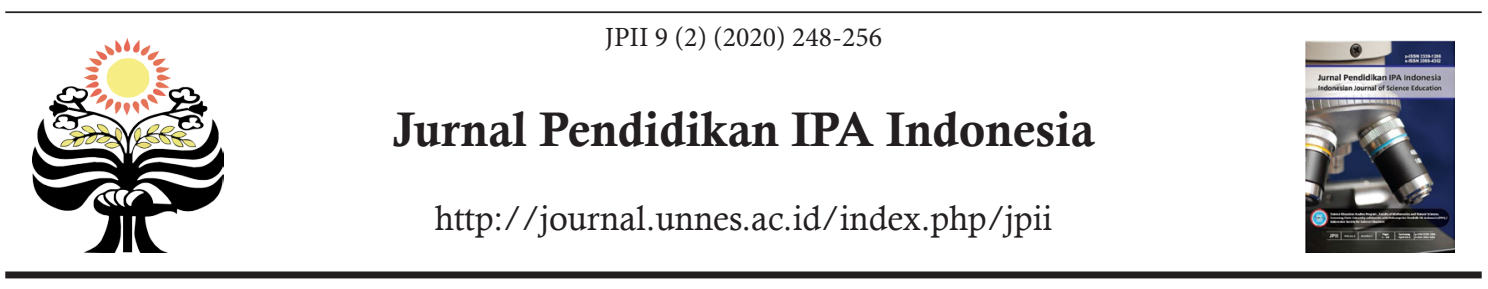

\title{
THE EFFECTIVENESS OF GADGET-BASED INTERACTIVE MULTIMEDIA IN IMPROVING GENERATION Z'S SCIENTIFIC LITERACY
}

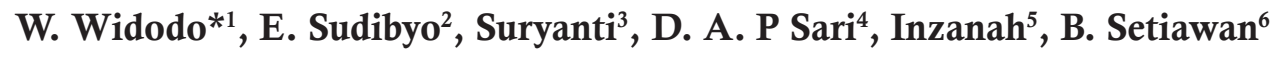 \\ ${ }^{1,2,4}$ Natural Science Department, Faculty of Mathematics and Natural Science, Universitas Negeri Surabaya \\ ${ }^{3}$ Elementary Education Department, Faculty of Education, Universitas Negeri Surabaya \\ ${ }^{5}$ Graduate of the Postgraduate of Science Education,Universitas Negeri Surabaya \\ ${ }^{6}$ Student of Department of Education and Human Potentials Development, National Dong Hwa University, \\ Taiwan
}

DOI: $10.15294 /$ jpii.v9i2.23208

Accepted: January $25^{\text {th }} 2020$. Approved: June $25^{\text {th }} 2020$. Published: June $30^{\text {th }} 2020$

\begin{abstract}
Scientific literacy is very important to generation Z (Gen-Z), while Gen-z's scientific literacy in Indonesia needs to be improved. The use of gadgets by Gen- $Z$ almost all the time in their daily lives enables research to improve scientific literacy by using gadgets. This study aims to determine the effectiveness of gadget-based interactive multimedia to improve Gen-Z scientific literacy and describe the Gen-Z response to interactive multimedia. This research was a pre-experiment study with one group pretest and posttest design. Interactive multimedia was designed to be applied on gadget, consists of Socioscientific Issues (SSI) which was relevant to pressure concepts. This research involved two junior high schools in East Java, Indonesia. Scientific literacy test instrument was designed based on scientific literacy aspects of PISA 2015. The inferential test results showed that posttest score was significantly greater than the pretest in the two schools. Results showed that the mean score of students' scientific literacy at School I increased from 39.6 to 74.0 and N-gain score was 0.57 which was in medium category. In addition, the average scientific literacy score of students in School II also increased from 31.5 to 59.9 and Ngain score was 0.41 which was in the medium category. The inferential test results also showed that there were no significant $\mathrm{N}$-gain differences in the two schools. It can be concluded that interactive multimedia developed effective to improve students' scientific literacy. However, Gen-Z students cannot be satisfied with the multimedia. Students suggest several multimedia enhancements in terms of visual, audio, and music, so that they can enjoy the multimedia all the time by using the device.
\end{abstract}

(C) 2020 Science Education Study Program FMIPA UNNES Semarang

Keywords: scientific literacy; generation Z; gadget-based interactive multimedia; socioscientific issues

\section{INTRODUCTION}

The $21^{\text {st }}$ century is a time in which humans live in a world that seems borderless. The flow of globalization, internationalization, and the development of information and communication technology happens so rapidly (Pendidikan \& Perak, 2013). There are four domains needed to be able to live in the $21^{\text {st }}$ century, namely digital literacy, inventive thinking, effective communication, and high productivity (Lemke et al., 2003).

*Correspondence Address

E-mail: wahonowidodo@unesa.ac.id
Scientific literacy is included in digital literacy domain (Lemke et al., 2003). Knowledge and understanding of the concepts and processes of science are needed by everyone to make decisions, participate in social life and cultural diversity, and also increase economic productivity. Scientific literacy is very important in modern society life which encountered issues related to science and technology (Pacific Policy Research Center, 2010). Thus, this literacy is needed for students nowadays. 
W. Widodo, E. Sudibyo, Suryanti,

Science education in Indonesia is in progressing. Since 2006 to 2018, scientific literacy score of Indonesian students was fluctuated from time to time (Organisation de coopération et de développement économiques, 2019). However, it is still below average level. This shows that scientific literacy of Indonesia students need to be improved with some efforts during learning process in school. Furthermore, this improvement can be achieved by applying creative ways that attract students' interest, so students become interested in reading, thinking, conducting investigations, and making decisions related to the issues given. For example giving an issues related to culture and daily life (Dewi et al., 2019; Ratini, et al., 2018; Alim et al., 2019).

Meanwhile, junior high school students, known as generation $\mathrm{Z}$ (Gen-Z), have a tendency cannot be separated from their gadget. An amount of 171.17 million active users utilize gadget to search for apps, games, and other digital content. More of that, almost every student of Primary to Senior High School Student already have gadget and operates it for daily activities. The result of survey conducted by Indonesia Internet Service Provider Association (2018) showed that $91 \%$ of people aged 15-19 year old use internet. In addition, the average time they spent to use internet daily via any device is 8 hours 36 minutes (APJII, 2018).

Those data suggested that junior high school students in Indonesia are addicted to gadget. Unfortunately, this addiction brings negative impact for students. They will be busy with their gadget, so they will not study over again or do their assignment. Nonetheless, their addiction to gadget can give students some advantages if they also use gadget to do something more productive, such as for learning some skills, for expanding the material they have learned at school, etc.

Based on preliminary research conducted in two junior high schools in East Java by interviewing teachers, it showed that they utilize the internet sometimes to access or look for some information related to learning. Teachers give students assignment or homework and students try to finish their assignment or homework with the help of the internet. Teachers never use a certain application or software as a media of learning. However, they are interested on using application or software to accomplish learning objectives.

These conditions can be utilized and provide a large space for teachers to use gadget as a tool to support science learning. Utilization of devices appropriately tends to generate student learning (Clayton \& Murphy, 2016). Gadget becomes a tool that makes students productive as long as directed by proper usage rules (Anshari et al., 2017). This is in accordance with $21^{\text {st }}$ century information, media, and technology skills. This skills demand students to be able to access, understand, and analyze media messages to find information and using technology (Pacific Policy Research Center, 2010).

Interactive multimedia is one of media that can use gadget in the form of digital application. Digital applications contribute significantly to the implementation of didactic principles and achievement of educational goals (Shi, 2013). Learning and teaching process supported by multimedia attracts students and the creation of correct conceptions (Chen, 2012). Multimedia and virtual reality makes the world more visible in ways that others have never known before (Bilek, 2012; Aberšek, 2013). Students prefer to learn something that facilitated by animation than facilitated by other representation (Naqvi et al., 2013). Theoretically, animation is more effective to portray movement or dynamic process. Thus, animator becomes attractive option for educators. Research of Taufiq, et al. (2016), Ismail et al. (2016), and Moore et al. (2014) confirm these statements.

Socioscientific Issues (SSI) learning based on issues in society related to science that students will investigate, has been studied can improve students' understanding, argumentation skills, empathy, and reasoning effectively about science in various life contexts (Wulandari et al., 2017), decision making (Siribunnam et al., 2014), proposed argument (Bilican, 2018), as well as environmental literacy (Kinslow et al., 2019). However, SSI learning to increase scientific literacy is still limited.

Some research were done in developing science learning media to enhance students' achievement, most of these studies showed positive outcome (Chee et al., 2017; Wu et al., 2012. However, research about gadget based interactive multimedia on pressure concepts, expecially to increase students' scientific literacy, is still limited. Even though there are many SSIs are related to the concept of pressure, for example tourists who died while diving in the Gili Meno Waters of Lombok, tourists can't wear high heels at ancient sites in Greece, and smoke from Indonesia's forest fires to neighboring countries due to wind. The SSIs can be used as a context for further investigation and decision making by students.

Interactive multimedia can be used as a platform to provide information, direction for investigations, and challenges for students to make 
decisions. By making interactive multimedia as an application program on gadgets, students can learn anywhere and anytime, something that Gen Z-likes. Furthermore, this will be answered through this research. Besides, there is limited information about students' feedback on a learning media, expecially their desire from those media. Based on this reason, the author has designed gadget-based interactive multimedia as a tool to enhance Gen-Z scientific literacy. Thus, it is necessary to conduct a research about the effectiveness of gadget-based interactive multimedia to improve students' scientific literacy and describe their response about interactive multimedia as generation $Z$. The features of multimedia contain of SSI relating to material pressure and its application in daily life, the relevant concepts to issues that are used as the topic, experiments to strengthen students' knowledge regarding concepts, the test used to measure students' scientific literacy, and it is equipped with a page link that can be used to determine the level of students' scientific literacy.

Based on the description, the problems are: (1) How is the effectiveness of gadget-based interactive multimedia to increase scientific literacy of Gen-Z students? (2) What is the response of Gen- $Z$ students to the gadget-based interactive multimedia?

This research aims to determine the effectiveness of gadget-based interactive multimedia to improve students' scientific literacy and to describe students' response about multimedia. By utilizing gadget to use interactive multimedia and involving socioscientific issues during learning process, it is expected to improve students' scientific literacy and to get students' response about the multimedia.

\section{METHODS}

This research was a pre-experimental study as a continuation of the designing phase and development of interactive multimedia in gadgets based on SSI, called gadget-based interactive multimedia (Widodo et al., 2019). The research design used was one group pretest and posttest design (Fraenkel et al., 2012) to determine the effectiveness of the gadget-based interactive multimedia in increasing students' scientific literacy. The gadget-based interactive multimedia is declared effective if there is a significant increase in scientific literacy of students after learning with the multimedia. The pre-experimental activity was replicated in 2 schools in East Java Indonesia, involving 30 students in School I and 25 students in School II.
The gadget-based interactive multimedia developed contains SSI that is relevant to the concepts of pressure. Thus, students can find out the applications and benefits of the concept of pressure they learn to respond to problems around them. These issues contain problems that require investigation and require students to be able to make decisions based on their knowledge.

The programs used in making apk consist of i-Spring, is software that can convert .PPT files into .swf. The Software Development Kit (Air_ SDK) is used to build Android applications, such as editing HTML and source code. Andaired, is software that can convert flash games into .apk. The IM-SSI-Gadget that has been developed has been declared feasible by 3 science education experts in terms of content, construction, and language (Widodo et al., 2019).

Data on student literacy skills were obtained through scientific literacy tests related to pressure concepts. The scientific literacy test instrument was developed from the aspects of PISA 2015 scientific literacy. The scientific literacy test used consisted of 15 multiple choice questions consisting of six questions with low cognitive demand (Lo), 4 questions with moderate cognitive demand $(\mathrm{M})$, and 5 questions with High cognitive demand (Hi).

The instrument was declared valid on content and construction by 3 experts and reliable with Cronbach's Alpha reliability of 0.555 in the significant category. The data were analyzed descriptively using cognitive demand level categories (Inzanah et al., 2017). The effectiveness of multimedia is seen from the increase in scientific literacy of students. The increase in scientific literacy of students was tested by inferential mean difference test. In addition, a normalized gains (N-gain) descriptive analysis is also carried out, as well as the $\mathrm{N}$-gain mean difference inferentially test between the two schools using SPSS 19.0.

\section{RESULTS AND DISCUSSION}

\section{Socio-Scientific Issues in Gadgets-Based Interactive Multimedia and its Learning Process}

Android platform gadget is needed to operate the interactive multimedia which is developed. Figure 1 shows the appearance of interactive multimedia.

The gadget based interactive multimedia is packaged in the form of an application file (.apk) that can be installed into an Android-platform gadget. The features contained in the interactive multmedia include: the initial display (contains 
W. Widodo, E. Sudibyo, Suryanti,

D.A.P Sari, Inzanah, B. Setiawan / JPII 9 (2) (2020) 248-256

the Home, Experiments, Exercises, and About menu), Home (contains the aims, concept map, and material menu), and check the level of scien- tific literacy pages. In addition, it also comes with a Home, Returns, and Checks Your Level of Scientific Literacy icon.

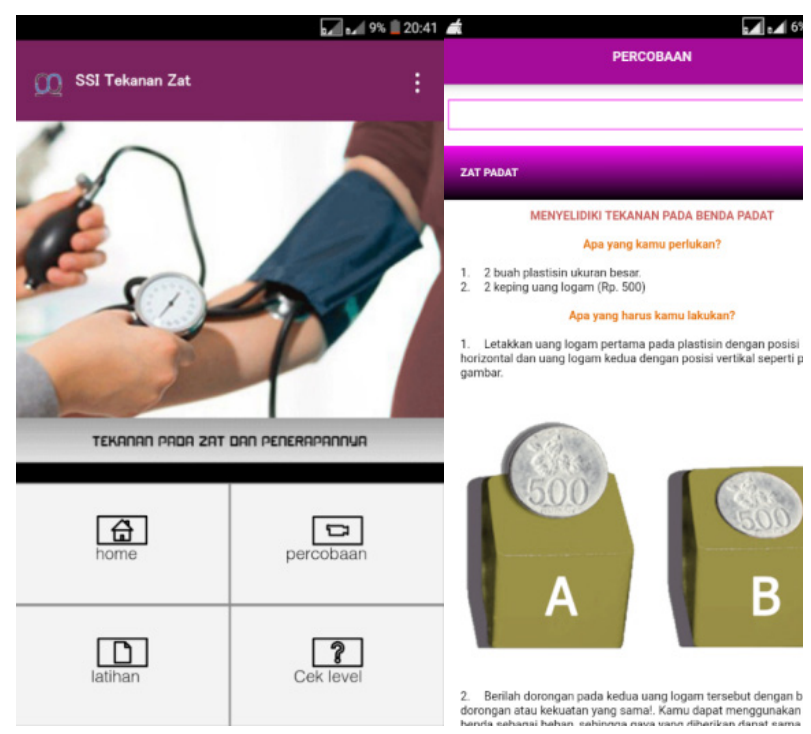

Figure 1. The Appearance of Gadget-based Interactive Multimedia

The gadget based interactive multimedia is packaged in text, image, and audio-visual-motion formats, contains SSI issues related to pressure concepts and its application in everyday life. These issues raise the problem used to investigate and learn the pressure concepts as well as its application in everyday life. Thus, students can find out the applications and benefits of the concept of pressure they learned to respond to issues around them, for example prohibiting the use of high heels when visiting a number of ancient monuments in Greece related to solid pressure material, the death of foreign tourists in Komodo Island is related to hydrostatic pressure concept, and the Indonesian submarine is surrounded by a NATO joint fleet in the Mediterranean Sea related to Archimedes' Law.

The gadget based interactive multimedia facilitates training and scientific literacy test. The scientific literacy test contains issues and allow students to use their knowledge to solve problems or make decisions related to the issues. The test consists of 15 multiple choices compiled and combined using new features in the PISA 2015 framework that incorporate the previous PISA frameworks, namely by using cognitive demand levels in scientific literacy assessment. Figure 1 shows the appearance of the interactive multimedia.

Learning activities carried out three times, outside of the pretest and posttest. Previously, students were given the opportunity to install gadget-based interactive multimedia into their gadget. At the first meeting, students discussed SSI about the prohibition of using high heel in ancient Greek monuments, investigated the pressure on solid substances, and discussed the reasons for the prohibition. At the second meeting, students discussed SSI about the death of a tourist while diving on Komodo Island, investigating the pressure on liquid, and discussing the relation of the event to the pressure on liquid and its effect on gas in the blood. As an extension, students discuss submarines in the "meeting" of Indonesian and NATO submarines related to Archimedes' Law. At the third meeting, Students discussed SSI about smoke from forest fires that could reach neighboring Indonesia, related to changes in air pressure. Students investigate more detailed information on weather patterns at the time, related to the dry or rainy season in Indonesia. Students are also encouraged to read and learn gadget-based interactive multimedia anytime and anywhere, according to their habits. 
Gen-z's Scientific Literacy

The percentage of students' scientific lite- racy (Gen-Z's scientific literacy) for each cognitive demand is presented in Table 1.

Table 1. Percentage of Students' Scientific Literacy for Each Cognitive Demand

\begin{tabular}{cccccccccc}
\hline \multirow{2}{*}{$\begin{array}{c}\text { School } \\
\text { Name }\end{array}$} & \multicolumn{8}{c}{ Percentage (\%) } \\
\cline { 2 - 10 } & L1 & L2 & N-Gain & M1 & M2 & N-Gain & H1 & H2 & N-Gain \\
\hline School I & 55.3 & 88.0 & 0.73 & 23.3 & 86.7 & 0.83 & 21.7 & 37.5 & 0.20 \\
School II & 44.0 & 65.6 & 0.50 & 23.3 & 54.0 & 0.40 & 28.0 & 60.0 & 0.44 \\
\hline
\end{tabular}

The results of the scientific literacy test are represented in the form of scoring and leveling. The analysis carried out included pretest and posttest data analysis which then calculated $\mathrm{N}$-gain scores to determine the increase in scores between before and after learning activities. Data processed from the pretest and posttest aims to determine the scientific literacy skills of students before and after learning activities.

Table 1 provides information regarding the percentage of students' scientific literacy from 2 pilot schools in solving questions in each cognitive scientific literacy requested, which includes low cognitive demand, namely L1 (pretest) and L2 (posttest), moderate cognitive demand, namely M1 (pretest) and M2 (posttest), and high cognitive demand, namely $\mathrm{H} 1$ (pretest) and $\mathrm{H} 2$ (posttest). Based on the table, it is known that the scientific literacy of students from 2 pilot schools has increased during learning process in medium category.

Students' scientific literacy of low and medium cognitive demand at School I increased and its N-Gain was 0.73 and 0.83 respectively, at high category. Scientific literacy on high cognitive demand also increased and its $\mathrm{N}$-gain was approximately 0.20 at low category. Meanwhile, N-gain score of students' scientific literacy of low, medium, and high cognitive demand were increase by $0.50,0.40$, and 0.44 at School II, at medium category.

The data on the results of overall students' scientific literacy tests from the two schools can be seen in the following tables.

Table 2. Results of the Scientific Literacy Test of Students

\begin{tabular}{cccccc}
\hline \multirow{2}{*}{ No. } & \multirow{2}{*}{ School Name } & \multicolumn{2}{c}{ Score } & \multirow{2}{*}{ N-gain Score } & Criteria \\
\cline { 3 - 4 } & School I & 39.6 & 74.0 & 0.57 & Medium \\
\hline 1 & School II & 31.5 & 59.9 & 0.41 & Medium \\
\hline
\end{tabular}

Table 2 provides information regarding overall scientific literacy scores that were obtained before and after participating in learning activities using the developed SSI Gadget. The average score of scientific literacy of students in School I was from 39.6 to 74.0 with $\mathrm{N}$-gain of 0.57 in the medium category. While the average score of scientific literacy of students in School II was from 31.5 to 59.9 with $\mathrm{N}$-gain of 0.41 in the medium category.

The results of the analysis show that the higher the cognitive demand, the smaller the $\mathrm{N}$ gain. In other words, it is more difficult to improve students' high-level cognitive skills. These results are consistent with Crompton et al. (2019) study which found that from the subjects integrating mobile devices, literacy studies had the highest percentage of students working in low cognitive levels (45\%).
In addition, difference test of pretest and posttest scientific literacy skills were performed with the Wilcoxon Signed Ranks Test. The nonparametric inferential test was chosen because the data did not meet the normality and homogeneity assumption test. Based on the results of the difference tests with SPSS 19.0, it was found that for School I: the value of $Z=-4.787, p=$ 0.000 which indicated the posttest scores was significantly higher than the pretest. Meanwhile, for School II, the value of $Z=-4,383, p=0,000$ which showed the posttest scores was significantly greater than the pretest. Thus, it appeared that the posttest scores of students from the two pilot schools were significantly greater than the pretest. These results indicate that Socio-Scientific Issues in gadgets-based interactive multimedia and its learning process are effective for increasing scientific literacy of Gen-Z students. 
W. Widodo, E. Sudibyo, Suryanti,

These results indicate, the learning process that discusses SSI, investigates, and practices making decisions, which is driven by gadget-based interactive multimedia can improve students' scientific literacy. With gadget-based interactive multimedia, it turns out learning activities tend to be student-centered, students investigate and learn to make decisions using real context. These results are in line with studies of Ardianto \& Rubini (2016) about using investigating methods to improve students' scientific literacy, Bustami et al. (2018) about the use of context and Cahyarini (2016) research that SSI allows students to enhanced critical thinking skills.

To study the consistency of treatment results at two schools, and $\mathrm{N}$-gain difference test was conducted between two schools with the Mann-Whitney U Test. The result was the value of $Z=-0,657(p=0.511)$ which showed no significant difference in the two schools.

The results of the analysis showed the achievement of $\mathrm{N}$-gain of the students from the two schools were not significantly different. This shows that the gadget-based interactive multimedia developed resulted an increase in scientific literacy that was relatively consistent in both schools. These results indicate the power of interactive multimedia to improve scientific literacy, in addition to positive responses from students, helped students to make connections between content and context (Mylott et al., 2016), critical thinking disposition (Gunawan et al., 2019), and meaningful understanding and retention of the conceptual structure of the domain, the concepts, and their relations (Marée al., 2013).

The impact of the interactive multimedia used in learning activities was that students could explore new concepts that were closer to their daily experiences and were able to explain science concepts well (Turiman, 2012). The convenience is seen from the change from the way of abstract thinking to the concrete way of thinking. So, it can indirectly increase students' interest in learning science process skills and the learning process becomes more effective.

The learning material prepared in accordance with the multimedia model supported by $7 \mathrm{E}$ positively influenced academic achievement and the information learned was more impressive (Sarac \& Tarhan, 2017). On the other hand, the results of the study show that using the SocioScientific Issues approach can improve students' ability to improve their decisions on environmental problems and the results show four patterns of student decisions (Zo'bi, 2014). Learning in the $21^{\text {st }}$ century should be linked to community life so students learn something like in real life. Integrating science subject on technology, such as using gadget, helps students to gain their skills both in science and technology (Asrizal et al., 2018). Thus, students can be prepared for future life.

\section{Gen-Z's Response to SSI-Gadget}

Gen-Z's response is the student's opinion on the quality of gadget-based interactive multimedia, which is viewed from the aspects of appearance, content, material, images/ animation/ video, operations, links, audio (narration), scientific literacy tests, and menu instructions contained within gadget-based interactive multimedia. The overall student response can be seen in Table 3.

Based on Table 3 it can be seen that the percentage of students' average responses to the quality of gadget-based interactive multimedia from the two schools of testing was $>80 \%$, which means that students give positives respond to learning activities using the developed gadgetbased interactive multimedia.

Table 3. Student Response to Gadget-based Interactive Multimedia Quality

\begin{tabular}{cccccc}
\hline \multirow{2}{*}{ No. } & \multirow{2}{*}{ School Name } & \multicolumn{4}{c}{ Percentage(\%) } \\
\cline { 3 - 6 } & & $\mathbf{1}^{\text {st }}$ Meeting & $\mathbf{2}^{\text {nd }}$ Meeting & Exercises & Response \\
\hline 1 & School I & 88 & 88 & 79 & 87 \\
2 & School II & 95 & 95 & 88 & 95 \\
\hline
\end{tabular}

In addition to the questionnaire, an open questionnaire also be given to students that ask students' impressions of learning activities using the developed gadget-based interactive multimedia. The learning activities that have taken place were very interesting and exciting ("...The learning activity is different than usual because involving mobile phone or gadget as a media, so it became more interesting and is not monotonous). They also said that teacher's explanation during the learning activity was clear and easy to understand. It was also not boring.

This gadget-based interactive multimedia helps students to understand the concept of substance pressure and its application in daily life. This application also helps students to solve the problem while sharpening their scientific literacy by providing students with some videos ("... 
the gadget based interactive multimedia is really good for learning because some videos help us to understand more about the concept..."). Furthermore, it helps students to do self-study and apply concept that they learn into their daily life.

'Check Level' feature also got positive respond. Students can measure their scientific literacy level easily and get the result just after they finish their test ("... the result of posttest in application makes me know the test result."). This feature support learning assessment, especially assess students' scientific literacy which is the goal of learning process. This is relevant to some studies that said that mobile device, in this study gadgetbased device, can support a wide range of assessment practices, such as self-assessment (Chen, 2010; Lai \& Hwang, 2015), high-stakes summative assessment (Arthur et al., 2014), formative assessment (Hwang \& Chang, 2011), performance assessment, or game-based assessments (Wang, 2015). Most of the result reported that positive student attitudes and perceptions about mobilebased assessment (Nikou \& Economides, 2018).

Student can easily learn whenever and wherever they want without teacher's guidance. Length of time is one of important factor that influence students' achievement. This factor probably increases students' motivation because students can access the material that they need to study during their 'dead time', such as when they wait for something or during their break time (Ushioda, 2013). It illustrates that interactive multimedia helps students to learn more. This is in accordance with benefit of learning media using gadget which is can be used anytime (Lesmono et al., 2018).

However, students can't be satisfied by only gadget-based interactive multimedia. They said they need more feature that can give more music, video, and interactive activity, such as discussion room or chatting room. They want to interact with other students. These suggestions show that gadget-based interactive multimedia expected multitasking activity while they operate gadget. In addition, students also want to play games while learning. Games not only makes learning more fun, but also can achieve learning goals as long as the game leads students to learn and to think more (Wardani et al., 2017).

It is also suggested that some feature to help students learn more about science vocabulary related to the topic is needed. This feature can be provided by word lists and/or cards methods to increase word repetitions. Furthermore, word lists or cards methods can be applied into game activities (Wu, 2015).

\section{CONCLUSION}

Based on the results of data analysis, it can be concluded that gadget-based interactive multimedia that contain SSI on pressure concepts is effective in improving Gen-Z's scientific literacy. However, Gen-Z is not easily serviced or not easily satisfied using the developed gadget-based interactive multimedia. This can be seen from the suggestions and comments given which indicate that they want a multitasking media, excellent graphic quality and illustrations, and so on. That is because Gen-Z grow up in the online world and spend thousands of hours in cyberspace by playing online games, sending messages and socializing using social media, using blogs, and so on with high-quality content. Future research can be done by utilizing SSI to improve literacy by using programs that are more interactive and multitasking so that the interactive multimedia developed can meet expectations of Gen-Z.

\section{REFERENCES}

Aberšek, B. (2013). Cogito ergo sum homomachine. Journal of Baltic Science Education, 12(3), 268270.

Alim, A., Sarwi, S., \& Subali, B. (2019). Implementation of Ethnoscience-based Guided Inquiry Learning on The Scientific Literacy and The Character of Elementary School Students. Journal of Primary Education, 8(5), 139-147.

Anshari, M., Almunawar, M. N., Shahrill, M., Wicaksono, D. K., \& Huda, M. (2017). Smartphones usage in the classrooms: Learning aid or interference?. Education and Information Technologies, 22(6), 3063-3079.

APJII, T. (2018). Potret Zaman Now Pengguna dan Perilaku Internet Indonesia. BUletin APJII, 1-7.

Ardianto, D., \& Rubini, B. (2016). Comparison of students' scientific literacy in integrated science learning through model of guided discovery and problem based learning. Jurnal Pendidikan IPA Indonesia, 5(1), 31-37.

Arthur Jr, W., Doverspike, D., Muñoz, G. J., Taylor, J. E., \& Carr, A. E. (2014). The use of mobile devices in high-stakes remotely delivered assessments and testing. International Journal of Selection and Assessment, 22(2), 113-123.

Asrizal, A., Amran, A., Ananda, A., Festiyed, F., \& Sumarmin, R. (2018). The development of integrated science instructional materials to improve students' digital literacy in scientific approach. Jurnal Pendidikan IPA Indonesia, 7(4), 442-450.

Bilek, M. (2012). Natural science education in the time of virtual worlds. Journal of Baltic Science Education, $9(1)$. 
W. Widodo, E. Sudibyo, Suryanti,

Bilican, K. (2018). Analysis of Pre-Service Science Teachers' Understanding of Nature of Science and Proposed Arguments on Socio-Scientific Issues. International Journal of Research in Education and Science, 4(2), 420-435.

Cahyarini, A., Rahayu, S., \& Yahmin, Y. (2016). The Effect of 5e Learning Cycle Instructional Model Using Socioscientific Issues (Ssi) Learning Context on Students' Critical Thinking. Jurnal Pendidikan IPA Indonesia, 5(2), 222-229.

Chee, K. N., Yahaya, N., Ibrahim, N. H., \& Hasan, M. N. (2017). Review of mobile learning trends 2010-2015: A meta-analysis. Journal of Educational Technology \& Society, 20(2), 113-126.

Chen, C. H. (2010). The implementation and evaluation of a mobile self-and peer-assessment system. Computers \& Education, 55(1), 229-236.

Chen, Y. T. (2012). A study of learning effects on elearning with interactive thematic video. Journal of Educational Computing Research, 47(3), 279-292.

Clayton, K., \& Murphy, A. (2016). Smartphone Apps in Education: Students Create Videos to Teach Smartphone Use as Tool for Learning. Journal of Media Literacy Education, 8(2), 99-109.

Crompton, H., Burke, D., \& Lin, Y. C. (2019). Mobile learning and student cognition: A systematic review of PK-12 research using Bloom's Taxonomy. British Journal of Educational Technology, 50(2), 684-701.

Dewi, C. A., Khery, Y., \& Erna, M. (2019). An ethnoscience study in chemistry learning to develop scientific literacy. Jurnal Pendidikan IPA Indonesia, 8(2), 279-287.

Fraenkel, J. R., Wallen, N. E., \& Hyun, H. H. (2011). How to design and evaluate research in education. New York: McGraw-Hill Humanities/ Social Sciences/Languages.

Gunawan, G., Harjono, A., Herayanti, L., \& Husein, S. (2019). Problem-Based Learning Approach with Supported Interactive Multimedia in Physics Course: Its Effects on Critical Thinking Disposition. Journal for the Education of Gifted Young Scientists, 7(4), 1075-1089.

Hwang, G. J., \& Chang, H. F. (2011). A formative assessment-based mobile learning approach to improving the learning attitudes and achievements of students. Computers \& Education, 56(4), 1023-1031.

Inzanah, I., Ibrahim, M., \& Widodo, W. (2017). Pengembangan perangkat pembelajaran ipa berbasis kurikulum 2013 untuk melatih literasi sains siswa SMP. JPPS (Jurnal Penelitian Pendidikan Sains), 4(1), 459-467.

Ismail, I., Permanasari, A., \& Setiawan, W. (2016). Stem Virtual Lab: an Alternative Practical Media to Enhance Student's Scientific Literacy. Jurnal Pendidikan IPA Indonesia, 5(2), 239-246.

Kinslow, A. T., Sadler, T. D., \& Nguyen, H. T. (2019). Socio-scientific reasoning and environmental literacy in a field-based ecology class. Environmental Education Research, 25(3), 388-410.

Lai, C. L., \& Hwang, G. J. (2015). An interactive peerassessment criteria development approach to improving students' art design performance using handheld devices. Computers \& Education, 85, 149-159.

Lemke, C., Coughlin, E., Thadani, V., \& Martin, C. (2003). en Gauge 21st century skills: Literacy in the digital age. USA: North central regional educational laboratory.

Lesmono, A. D., Bachtiar, R. W., Maryani, M., \& Muzdalifah, A. (2018). The InstructionalBased Andro-Web Comics on Work and Energy Topic for Senior High School Students. Jurnal Pendidikan IPA Indonesia, 7(2), 147-153.

Marée, T. J., van Bruggen, J. M., \& Jochems, W. M. (2013). Effective self-regulated science learning through multimedia-enriched skeleton concept maps. Research in Science \& Technological Education, 31(1), 16-30.

Moore, E. B., Chamberlain, J. M., Parson, R., \& Perkins, K. K. (2014). PhET interactive simulations: Transformative tools for teaching chemistry. Journal of Chemical Education, 91(8), 1191-1197.

Mylott, E., Kutschera, E., Dunlap, J. C., Christensen, W., \& Widenhorn, R. (2016). Using biomedically relevant multimedia content in an introductory physics course for life science and prehealth students. Journal of Science Education and Technology, 25(2), 222-231.

Naqvi, S. H., Mobasher, F., Afzal, M. A., Umair, M., Kohli, A. N., \& Bukhari, M. H. (2013). Effectiveness of teaching methods in a medical institute: perceptions of medical students to teaching aids. $J$ Pak Med Assoc, 63(7), 859-64.

Nikou, S. A., \& Economides, A. A. (2018). Mobilebased assessment: A literature review of publications in major referred journals from 2009 to 2018. Computers \& Education, 125, 101-119.

Organisation de coopération et de développement économiques. (2019). PISA 2018 Assessment and Analytical Framework. OECD Publishing.

Pacific Policy Research Center. (2010). 21st century skills for students and teachers. Research and Evaluation, 1-25.

Pendidikan, P. I. P., \& Perak, H. (2013). Kementerian Pendidikan Malaysia. Pelan Pembangunan Pendidikan Malaysia (PPPM), 2025.

Ratini, R., Muchtar, H., Suparman, M. A., Tamuri, A. H., \& Susanto, E. (2018). The Influence of Learning Models and Learning Reliance on Students' Scientific Literacy. Jurnal Pendidikan IPA Indonesia, 7(4), 458-466.

Sarac, H., \& Tarhan, D. (2017). Effect of Multimedia Assisted 7e Learning Model Applications on Academic Achievement and Retention in Students. European Journal of Educational Research, 6(3), 299-311. 
W. Widodo, E. Sudibyo, Suryanti,

D.A.P Sari, Inzanah, B. Setiawan / JPII 9 (2) (2020) 248-256

Shi, W. Z. (2013). The Effect Of Peer Interactions On Quantum Physics: A Study From China. Journal of Baltic Science Education, 12(2).

Siribunnam, S., Nuangchalerm, P., \& Jansawang, N. (2014). Socio-Scientific Decision Making in the Science Classroom. Online Submission, 5(4), 1777-1782.

Taufiq, M., Amalia, A. V., Parmin, P., \& Leviana, A. (2016). Design of science mobile learning of eclipse phenomena with conservation insight android-based app inventor 2. Jurnal Pendidikan IPA Indonesia, 5(2), 291-298.

Turiman, P., Omar, J., Daud, A. M., \& Osman, K. (2012). Fostering the 21 st century skills through scientific literacy and science process skills. Procedia-Social and Behavioral Sciences, 59, 110-116.

Ushioda, E. (2013). Motivation and ELT: Looking ahead to the future. In International perspectives on motivation (pp. 233-239). Palgrave Macmillan, London.

Wang, A. I. (2015). The wear out effect of a gamebased student response system. Computers \& Education, 82, 217-227.

Wardani, S., Lindawati, L., \& Kusuma, S. B. W. (2017). The development of inquiry by using android-system-based chemistry board game to improve learning outcome and critical thinking ability. Jurnal Pendidikan IPA Indonesia, 6(2), 196-205.

Wen, C. T., Liu, C. C., Chang, H. Y., Chang, C. J., Chang, M. H., Chiang, S. H. F., ... \& Hwang, F.
K. (2020). Students' guided inquiry with simulation and its relation to school science achievement and scientific literacy. Computers \& Education, 149, 103830.

Widodo, W., Sudibyo, E., \& Sari, D. A. (2019, January). Socio-scientific issues in gadget: interactive multimedia to increase $\mathrm{z}$-generation scientific literacy. In International Conference on Science, Technology, Education, Arts, Culture and Humanity-" Interdisciplinary Challenges for $\mathrm{Hu}$ manity Education in Digital Era"(STEACH 2018). Atlantis Press.

Wu, Q. (2015). Designing a smartphone app to teach English (L2) vocabulary. Computers \& Education, 85, 170-179.

Wu, W. H., Wu, Y. C. J., Chen, C. Y., Kao, H. Y., Lin, C. H., \& Huang, S. H. (2012). Review of trends from mobile learning studies: A meta-analysis. Computers \& Education, 59(2), 817-827.

Wulandarai, F., Handoko, A., \& Anggoro, B. S. (2017). Pengaruh Penggunaan Strategi Socio Scientific Issues Terhadap Reflective Judgment Siswa Kelas Ix Di Smp Negeri 11 Bandar Lampung. Biosfer: Jurnal Tadris Biologi, 8(1), 1-12.

Zo'bi, A. S. (2014). The Effect of Using Socio-Scientific Issues Approach in Teaching Environmental Issues on Improving the Students' Ability of Making Appropriate Decisions towards These Issues. International Education Studies, 7(8), 113123. 